\title{
Gratia omnibus
}

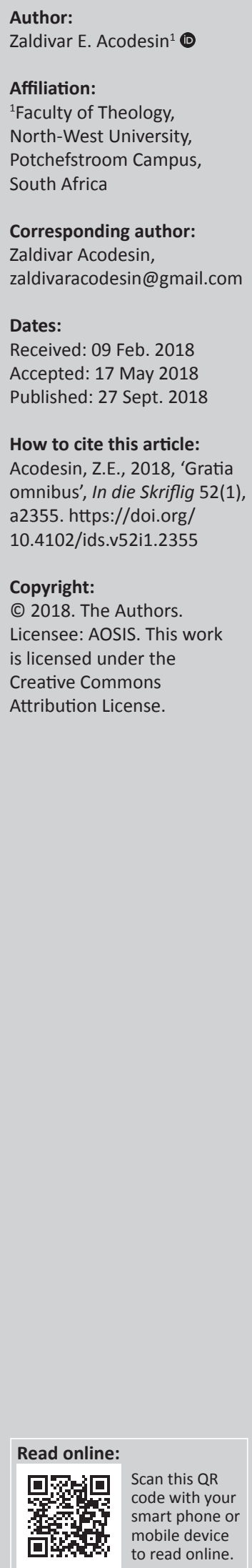

\begin{abstract}
This article attempts to compare the anthropological theories of the different positions concerning the grace doctrine. The article finds that the anthropological perspective of the nature of human beings in the state of sin is controlling in determining beliefs in the theology of sanctification and salvation, and dictates the Christian walk, especially with regard to the confession of sin. The article concludes that if there is error in the understanding of human anthropological origin, then there is error in the understanding of the application of grace unto salvation. It stresses that Scripture should be the ultimate standard under which anthologies of grace should be examined. The article also advances the relevance of traditions in modern Christianity. The doctrine of grace will be briefly investigated through the exegesis of Paul's letter to the Ephesians, particularly 1:4-7 and 2:8-9. The Calvinistic apologetics on the doctrines of grace is referred to throughout the article.
\end{abstract}

\section{Introduction}

Is God's grace a mere comforting embrace for the sinner or is it an enabling and directing power which drives Christians towards holy living?

The role of God's grace is arguably the topic of many debates in Christianity. Ryrie (1963:10-11) writes that grace is 'the watershed that divides Catholicism from Protestantism, Calvinism from Arminianism, and modern theological liberalism from theological conservatism'. From it flow numerous, diverse and even conflicting theological Christian doctrines on human salvation. While it has been plainly and generally characterised as a gift from God, freely given for human salvation, debates as to its precise substance and role, is still unsettled (Kainer 2015:1, 7-12). Robichaux (2000:5) observes that there is a 'wide spectrum of definitions of what grace is among various faith traditions within the Christian church'. Gaffin (2006:10) points out that there is an 'undeniable state of affairs: the problematic nature of Pauline interpretation that has proven to be the case down through the history of the church to the present'.

Grace is a fundamental concept in Christianity. Machen (cited by Bufford 2015:10) even says that it is the 'very centre and core of the whole Bible'. It is the ultimate manifestation of the immense love of God, the very foundation of the gospel, profoundly shown to the sinners. Warfield (2000:44) states that 'it is in almighty grace that a sinner can hope'. After all, it is through grace that the human interminable predicament, death, in its eventual sense, has been obliterated once and for all. A compact of this elementary gospel message can be found in John 3:16 which Luther famously referred to as the 'heart of the Bible, the gospel in miniature' (see Drury 2006). While there is no question that God loves humanity, we may, however, inquire as to the extent of his love for the sinner. Such a question draws different answers across the spectrum of Christian beliefs. Ultimately, the answers would depend on the understanding of the role of grace and its functional extent in the salvation narrative. This results to a mounting dilemma in the Christian church. While various Christian groups claim that their institutional definition of grace is a faithful interpretation of the Bible, all seem more caught up in dissimilarities than in accord (cf. Yarchin 2004:xi). In the search to satisfy a concrete characterisation of grace, some rely strictly on only one version of a truth of the Bible, some blindly patronise teachers of the Word, insisting on progressive and 'new' revelations, labelling themselves as 'revolutionists', while some are rigid in their religiosity to teachings they have accepted as convention (cf. Gaffin 2006:1).

In general, we can identify three kinds of Christian orientations on the implications of God's grace: The first orientation that God's grace results to the absolute application of God's love towards sinners so that they become perfect, blameless and absolutely absolved of any implications of sin. The second argues for a partial application of God's grace so that, while God shows his love for the sinner, the sinner needs to cooperate with God's gift to achieve salvation. The third denies any application of grace which results a full reliance on the ability of the sinner to work towards salvation. In these orientations are inroads that need to be nuanced and should 
be subjected to critical analysis whether they are indeed hinged on biblical truth. Needless to say, the litmus of faiths should be the gospel truth, and whatever contradicts Scripture in any way, shall be out-rightly dismissed and treated as mere hypothesis. The challenge then is to be adept in Scripture so that there can be an immediate recognition and separation of truth from mere conjectures. Hence, there is a need to trace concepts from their sources. This article insists on tracing the origins of the doctrine of God's grace to Paul who is otherwise called the Apostle of Grace. This means a study of Scripture, but a mere study should not suffice; the study should follow the ultimate standard of veracity and it should be thorough and in-depth. This article attempts to subject the anthologies of grace to the redemptivehistorical framework where theologies on the nature of human beings will be analysed as to their implications to the sinners' salvation.

Gaffin (2012:91) explains that the Scripture is an account of 'inexorable forward movement of history, in all of its twists and turns, towards its intended goal, Christ'. Through the redemptive-historical view, readers of the Bible are urged to trace passages to its ultimate reference point: the cross of Christ - a story of how God is redeeming a people unto himself through Christ. This is similar to what Paul said of the gospel message (1 Cor 15). Paul bears witness to the traditioning of God's grace administration. He said:

... be able to understand my insight into the mystery of Christ, which was not made known to men in other generations ... His intent was that, through the church, the manifold wisdom of God should be made known ... (Eph 3:4-10 - New International Version [NIV])

Simply, the goal of this article is to relay to the reader that a faithful understanding of grace should always be rooted their Scripture. That said, whatever message is not in accordance with Pauline grace, which is scriptural grace, is exclusively false grace. The following subsections will explore why it is imperative to have a correct understanding of the nature of sinners while they were not saved. The implications of God's grace and its role for human salvation.

\section{Pauline grace}

The authors of the Bible were God-inspired and spirit-filled writers. God called his writers and allowed them to see his wonders and hear his voice so that they could pen the chronology of God's works in history. 2 Timothy 3:16 bears witness to this truth: 'All Scripture is God-breathed.' Among these writers is Paul. ${ }^{1} \mathrm{He}$ is undeniably one of the greatest Christian figures apart from Christ himself (Becker 1993:1, 5). Paul was a Roman citizen (Ac 22:25-29). ${ }^{2}$ He introduced the God of the Jews to the Gentiles and drew the Gentiles into a

1.After his conversion, he preferred to be called by his Roman name, Paul, rather than his Hebrew name, Saul.

2.In Paul's time, being a Roman citizen entails that one is privileged:

To the Roman his citizenship was his passport in distant lands, his talisman in seasons of difficulties and danger; it shielded him alike from the caprice of
municipal law and the injustice of local magistrates. (see The International municipal law and the injustice of local magistrates. (see The International Standard Bible Encyclopaedia 1986:2273). relationship with God. Paul himself acknowledged this responsibility to introduce God to the Gentiles and he emphasised this in his writings (Col 1:27; 1 Tm 2:7; Rm 1:5; 15:15-18). Thus, he came to be known by many as the Apostle to the Gentiles (cf. Eph 3:1) because he was one of those who severed the notion that the word of God is exclusive only to the Jews. He reiterated in his writings the grant of salvation even to the undeserving. It is in Ephesians 2:8-9 (NIV) where he wrote:

For it is by grace you have been saved, through faith - and this is not from yourselves, it is the gift of God - not by works, so that no one can boast.

According to Arnold (2008:21), Ephesians best narrates what it means to be a Christian, as it clarifies the 'heart of the Christian faith'. Carson and Moo (2009:479-497), Heil (2007:4-6), Hoehner (2002:2-77), O'Brien (1979:504-516) and Schreiner (2011:11-30) are convinced that Ephesians is written by Paul. ${ }^{3}$ It is worth noting that Paul wrote to the Ephesians, because they once have heard the gospel message of grace (cf. Eph 3:2ff.). This letter of Paul to the Ephesians has hugely influenced Christian thought. Although Paul writes of God's grace in his other epistles such as in Romans and Galatians, it is in Ephesians where Paul best articulates God's gift of grace to the sinners. After all, it is in Ephesians 3:2 that Paul tells us about the administration of God's grace given to him. Scholars agree that Paul's letter to the Ephesians is one of his more meaningful works. Bruce (1984:229) calls Ephesians 'the quintessence of Paulinism', because it 'in large measure sums up the leading themes of the Pauline epistles, and at the same time the central motive of Paul's ministry as the Apostle to the Gentiles'. Dodd (1929:1224-1225) and Robinson (1907:vii) called Ephesians the 'crown of St. Paul's writings' and the 'crown of Paulinism', respectively. Coleridge (1858:82) wrote that Ephesians is 'one of the divinest compositions of human being, it embraces every doctrine of Christianity'. Calvin (cited by Kostenberger, Kellum \& Quarles 2012:241) even referred to it as his favourite letter.

Paul's writings on grace have been underscored in his letter to the church in Ephesians. It is for these reasons that we delve into the study of this letter to find Paul's thoughts on grace and associate them with what the other passages in the Bible have to say about God's grace in light of Christ's works for the salvation of the sinner.

Gaffin (2006:6) proposes a way of understanding Paul through the redemptive-historical perspective which insists that traditions and the passages of the Scripture are not mere moral guides for the believer to live a faithful Christian life. Scripture should rather be studied to unravel revelations of Christ and his works for the salvation of sinners (Russell 1995:335-357) - that biblical-theological approach must always be done with the recognition that each writer is a part of a much larger (historical) context with the purpose

3.See also Arnold's Ephesians (2011:46-50) which summarises the key reasons why scholars and commentators are convinced that Ephesians is an authentic Pauline letter. 
of directing those biblical knowledge to understand how sinners are redeemed. Each, with his or her distinctive contribution, functions in the unfolding history of God's self-revelation. God's verbal self-revelation has its rationale, as it is tethered to and is part of a larger totality of the overall history of redemption and accompanying revelation, of attesting and interpreting revelatory word focused on the redemptive deed. In this way, we follow the lead of the New Testament writers who understood the texts of the Bible in their redemptive-historical setting and treated the texts in relation to the ultimate biblical goal of fulfilment in Christ (McCartney 2003).

Despite having Paul's writings in the Bible as the main source for the explanation of the doctrine of grace, there is an inundation of diverse scholarly outputs on the meaning of grace, its effects on sin and its role in the salvation of the sinner. ${ }^{4}$ Instead of clarification, the numerous writings seem to complicate its meaning and implication. Peter wrote about the tendency and danger of misunderstanding Paul:

He [Paul] writes the same way in all his letters, speaking in them of these matters. His letters contain some things that are hard to understand, which ignorant and unstable people distort, as they do the other Scriptures, to their own destruction. (2 Pt 3:16 NIV)

In Ephesians, Paul says of grace:

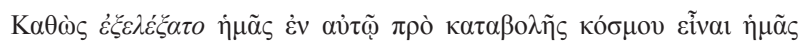

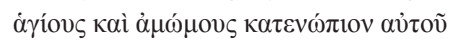

[For He chose us in Him before the creation of the world to be holy and blameless in His sight.]

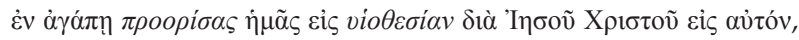

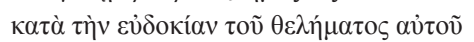

[In love He (God) predestined us to be adopted as His sons through Jesus Christ, in accordance with His pleasure and will ...]

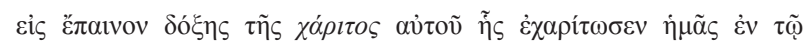
$\grave{\eta} \gamma \alpha \pi \eta \mu \varepsilon \dot{\varepsilon} \omega$

[to the praise of His glorious grace, which He has freely given us in the One He loves.]

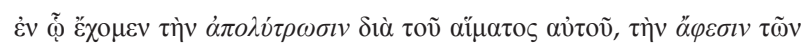

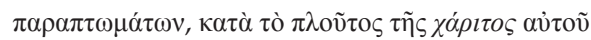

[In Him we have redemption through His blood, the forgiveness of sins,

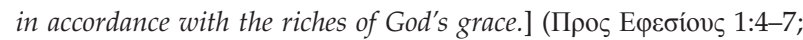
Nestle 1967:490 [Eph 1:4-7 - NIV], [author's emphasis])

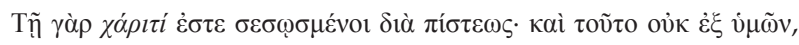

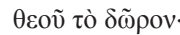

[For it is by grace you have been saved, through faith - and this not from yourselves, it is the gift of God ...].

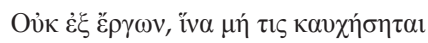

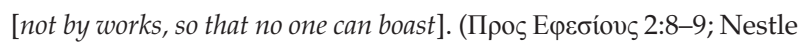
1967:492 [Eph 2:8-9 - NIV], [author's emphasis])

In trying to arrive at the truth intended by the two passages, it is necessary to pay attention to the words used. Thus, it is

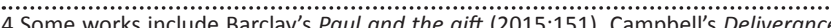
of God (2009:172), Chersters Reading Paul with the Reformers (2017:322), Dunn's of God (2009:172), Chester's Red Theology of Paul the apostle (1998:335), Sanders' Paul and Palestinian Judaism (1977:i), Stuhlmacher's Revisiting Paul's doctrine of justification (2001:75); Wright's Paul and the faithfulness of God (2013:1320). vital to discuss the original meaning of certain keywords and phrases (found in both the epistles and other supporting passages) in examining the focus verses.

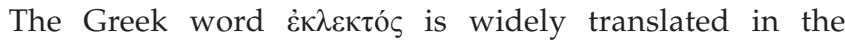
standard versions by such English terms as elect or chosen (Wigram \& Winter 1978:228). It is derived from the verb form $\dot{\varepsilon} \kappa \lambda \dot{\varepsilon} \gamma o \mu \alpha t^{5}$ (cf. McCarthy 2010:1). It is the only form occurring in one of the texts considered in this article (Eph 1:4). However, many of the other 51 verses, concerning this keyword, could have been included, because they are related to the idea of election, foreordination and predestination. For instance, John 15:15-16 tells us that no one but God the Father can exercise choice in the

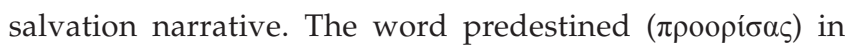
verse Ephesians 1:5 is equivalent to the term foreordained (Whitford 2012:87) which is a compound word from $\pi \rho$ ó - a primary preposition which means 'in front of' or 'prior to' (figuratively superior), ${ }^{6}$ and from ópí̧ which means to mark out or bound (horizon), that is, (figuratively) to appoint, decree or specify: declare, determine, limit or ordain (Strong 1997:341). Thayer's definition of the verb $\pi \rho o o \rho i ́ \zeta \omega$ is to predetermine or decide beforehand: God's decree from eternity to foreordain and appoint beforehand (Meyers 2016b). This keyword is the crux to understand the controversy between the advocates of the human free will and those who argue for a deterministic foreordination and predestination (i.e. those who stress that both the saved and the lost were 'elected' before the foundation of the world) (Lindsay 1939). The doctrine of deterministic predestination and foreordination was settled by John Calvin. Calvin (1961:27) taught that predestination is the eternal decree of God by which he decided before the foundation of the world what is to become of each and every individual. On the other hand, Arminius (1853:268), Wesley (1755:11) and their followers resisted the Calvinistic interpretation and set forth a theology of their own, advocating for the free will and free moral agency of every person.

The understanding of grace in Ephesians 2:8-9 entails the espousal of the concept of spiritual death referred to in verse one as the default state of all sinners. The words hath he quickened are italicised in some Bible versions like the King James Version to show that it does not reflect its original text. In many other translations, the phrase is altogether omitted. Thus, Ephesians 2:1 should mean that sinners are dead in trespasses and sins. The verse refers to a spiritual death, not a physical one (Berkhof 1996:260). The Greek word for death is veкрó $\varsigma$ which can mean either the death of the body or the death of the spirit. When the Bible talks about death, it is generally not talking about the cessation of life, but more of separation (Jakes 2008:82). In that sense, the spirit, which is dead, is separated from God and cannot relate to or function in God's kingdom. This state of being spiritually dead is due to our trespasses and sins. Sin separates us from God spiritually. Paul wrote that all were dead in trespasses and sins.

5.This is used 21 times in the New Testament.

6.It can also mean above, ago, before, or ever (see Meyers 2016a). 
Trespass is expressed by $\pi \alpha \rho \alpha ́ \pi \tau \omega \mu \alpha$ which we could be described as the acts of slipping off the right path, erring, or wandering away from what is good (Strong 1997:360). The

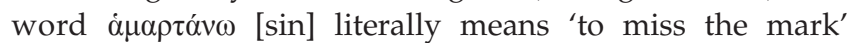
(Strong 1997:26). П $\alpha \rho \alpha i \pi \tau \omega$ and $\alpha \mu \alpha \rho \tau \alpha \dot{v} \omega$ refer to the act of throwing a spear and missing the target - the failure to achieve a purpose or a goal (Strong 1997:359). Paul stresses that when we are separated from God; thus, all works on our part eventually misses and wanders off from the will of God, and will always fall short of the standard of God. Due to our miserable condition and spiritual frustrations, there is utter need for God to lead us away from the darkness and from futility towards a life for and with him. John 3:16 tells us that it is God's love for all sinners that provided Jesus as the remedy for sin. 'God made Him, who has no sin, to bear our sin, so that in Him we can become the righteousness of God' (Rm 5:17). God recognises that sinners are spiritually dead; thus, no intimate fellowship can be had with him. Therefore, God elected believers and drew them to believe in him (Eph 1:4), He, himself, devised a way to draw his people to him and have that fellowship which once was lost due to sin. He predestined (Eph 1:5) and plucked sinners from death (Eph 2:1), even if there is no merit to bank from such gratuity. This is the perfect manifestation of God's grace.

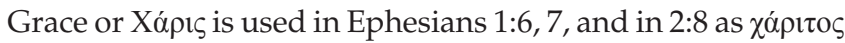
and $\chi \alpha \dot{\alpha} \iota \tau^{\prime}$. Xópı $\varsigma^{7}$ meaning graciousness (as gratifying) of manner or act (abstract or concrete, literal, figurative or spiritual, especially the divine influence upon the heart and its reflection in the life, including gratitude) which is acceptable, beneficial, favourable, joyous, liberal, pleasurable and thankworthy (Strong 1997:521, 523). Grace (Xópıs) then is the divine influence upon the heart which results to something that is thankworthy. To Thayer (1996:665-666),

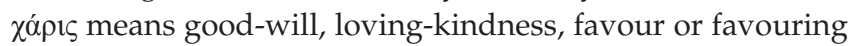
(as also used in Lk 2:52; 2 Cor 8:4), to have favour with one (cf. Ac 2:47, 7:10), attends and assists one (cf. Lk 2:40, Ac 4:33). Xópıs refers to the kindness of a master towards the inferiors or servants, especially of God towards humans (Lk 1:30). This wins for us God's favour (1 Pt 2:19; Ac 14:26; 15:40). Christ's grace is further described as the mercy shown towards human sinfulness. By grace, Christ relinquished his original status of divine blessedness (Rondinone 2012:174) and voluntarily underwent the hardships and miseries of ordinary human life so that, by his sufferings and death, he secured salvation for humanity (Ac 15:11; 2 Cor 8:9; Rm 5:15; Gl 1:6; Tt 3:7; Jn 1:14, 17). Xópıs is, according to Thayer (1996):

the merciful kindness by which God, exerting His holy influence upon souls, turns them to Christ, keeps, strengthens, increases them in Christian faith, knowledge, affection, and kindles them to the exercise of the Christian virtues. (pp. 665-666)

Because 'death' means a separation from God, sinners cannot therefore independently endeavour to move themselves from damnation to salvation, because the holiness of God requires a standard too high to be reached by human effort alone. Thus, by God's grace, he allowed a remedy for us to be 7.Xópiç is used here as a noun derived from the primary verb $\chi \alpha i p \omega$. engrafted in his kingdom so that we may become the sons and daughters of God by adoption through Christ.

Adoption or viofería in Ephesians 1:5 means 'placing as a son' into the divine family (Strong 1997:494). To Thayer $(1996: 397,1206)$, it is the nature and condition of the true disciples of Christ who, by receiving the Spirit of God, become the children of God ( $R m$ 8:15; Gl 4:5). It also includes the blessed state in the future life after the return of Christ ( $\dot{\alpha} \pi \varepsilon \kappa \delta \varepsilon \dot{\chi} \varepsilon \sigma \theta \alpha$ vio $\theta \varepsilon \sigma i \alpha v)$ - to wait for adoption, that is, the consummate condition of the children of God which will render it evident that they belong to God ( $\operatorname{Rm} 8: 19,23)$. According to Scofield (2004:1556), the believers' relation to God as children results from the new birth (Jn 1:12-13). Adoption is God's act whereby one is placed in the position of a child through redemption (Gl 4:1-5). The indwelling spirit gives the realisation of this in the believer's present experience (G1 4:6), but the full manifestation of the believer's adoption awaits the resurrection where transformation of saints may be. Such phenomena is called 'the redemption of the body' (Rm 8:23; 1 Th 4:14-17; Eph 1:14; 1 Jn 3:2).

The Pauline understanding of the word adoption can also mean justification. Paul writes of sin and justification in relation to two figures: Adam and Christ (Moo 1996:29). Through Adam, sin and death have come into the world; through Christ, righteousness has come into the world bringing justification. Romans 5:18 says, 'Consequently, just as one trespass resulted in condemnation for all people, so also one righteous act resulted in justification and life for all people.' According to Paul, history is divided into two eras, each under its own regime - Adam and Christ respectively (Barclay 1988:98). Each has their respective characterisation: sin, the law, flesh and death on the one hand, and righteousness, grace, the spirit and life on the other (Moo 1996:28) - the old and the new era.

Westerholm (1992:167) explains that all are, by default, under the regime of the old era, because the Adamic nature or sin (Rm 5:12) is inherited and passed on to every human being. However, by being joined to Christ through faith (Rm 6:1-6), there can be a change of regime. This option of coming to the new era is in itself an expression of God's grace, because by the sin of Adam, death would have been the ultimate sanction. According to Furnish (1968:135), '[j] ustification by faith is ultimately a determinative to Paul's salvation historical scheme'. This does not mean an automatic appropriation of Christ's works. Therefore, the person who lives after Christ's death and resurrection, but has not appropriated the benefits of those events of the new era, is still in the old era, and thus still enslaved to sin in the flesh and doomed to eternal death.

In relation to the church, Westerholm (1992:168) rightly suggests that justification by faith is central to Paul's theology, because it expresses a crucial element in Paul's understanding of God's works in Christ and by extension - the church. Carson (1992:67) writes that there is a clear eschatological 
sense implied in Paul's usage of the term justification. In Romans 8:30, Paul relates justification with predestination and glorification. He further states that those who are justified, cannot be separated from Christ (Rm 8:33-39). In Romans 8:16-19, Paul clearly states that believers in Christ, through faith, are already children of God in the present, but their 'adoption' is not yet fully manifested. Robinson (1979:121), likewise understands that justification, in the present tense in Romans 3:28, shows that the 'process' of being made right before God is initiated in this life and brought to completion in the final judgement. Within justification, there is a vindication for the believer that will not take place until the last day (Westerholm 1992:201). While our salvation is secured through Christ's death and applied to us through faith (Rm 6), vindication will be fully manifested in the completion of our justification at the final judgement of God (Mt 25). Now the spiritually dead, made alive by the adoption or justification through Christ, has been enabled to 'walk in unity' (Eph 4:1-16), 'in holiness' (4:17-23), 'in love' (5:1-6), 'in light' (5:7-14), 'in wisdom' (5:15-6:9), and to stand in warfare (6:10-20) by the Spirit of God (cf. Hoehner 2002:497-817). According to Heil (2007:1-4, 93-278) the word walks in Ephesians means 'empowerment' to live for the unity of all in Christ. The Greek word for 'walk' is $\pi \varepsilon \rho \imath \pi \alpha \tau \dot{\varepsilon} \omega$ which means to live, deport oneself, to follow (Strong 1997:374). Therefore, by grace, God enables Christians to walk by faith in their Christian life.

Ephesians 1:3 talks of the many spiritual blessings in Christ - one of which is redemption ( $\tau \hat{v} v \dot{\alpha} \pi \mathrm{\alpha} \lambda \hat{\tau} \tau \rho \omega \sigma v)$ (see Meyers 2016c). It is a redemption through blood, because the proper and commensurate indemnity for sin is blood, being the emblem of cleansing (see Bible Hub 2016). Such cleaning may only be had in union with Christ. This includes the forgiveness of sin which is not merely a privilege of the future, but of the present. According to Thayer (cited by Meyers 2016d), ä $\varphi \varepsilon \sigma 1 \varsigma$ [forgiveness] denotes a release from bondage or imprisonment which is synonymous to the meaning conveyed in Psalm 103:12 (NIV): 'As far as the east is from the west, so far has He removed our transgressions from us', according to the riches of his grace. The completeness of the forgiveness, the security of its being continued in the future and similar qualities show the richness of God's grace (Mt 18:27; Lk 7:42, 47).

According to Mueller (1982:24), the salvific act of God or the redemptive work of Christ has two dimensions: The first enables the believers to glorify God, to be like Christ and to be spiritually alive through the spirit or the i $\lambda$ á $\sigma \kappa o \mu \alpha$ [hilaskomai] as used in Hebrews 2:17 (Strong 1997:229) which is the reconciliation of all through Christ's blood or the $\kappa \alpha \tau \alpha \lambda \lambda \dot{\alpha} \sigma \sigma \omega$ [katallasso] used in 2 Corinthians 5:18-20 (p. 249). For Paul, grace is that enabling power of God to draw us towards God - exclusive only through God's pleasure and will (Eph 1:5) so that no one should boast (2:8-9).

God framed this good news to show every generation his immense love through his only son's death on the cross.
This is the grace message: that we have been enabled to live a Christian life despite our very nature: defiled, sinful, depraved, separated and spiritually dead. The realisation of the nature of human beings before salvation is of utmost importance for the understanding of the gospel message and the appreciation of God's grace. Knowledge of our miserable selves leads us to a desperation to know God (cf. Inst.1.1.1). Only when we see that once we were nothing, but that God, by his sovereign will, granted salvation to his people, can we acknowledge how profound, amazing and great the gospel message is. Thus, we come to faithfully follow it even when some ends still lie loose in our human understanding. We come to realise that God is amazing in his love and grace for us and sovereign in his plan for all.

\section{Pelaguis, Augustine, Semi-Pelagianism, Wesley, and the reformed tradition on grace}

In church history, the study on human fall has been made an issue by Pelagius and Augustine. The discussion on the role of grace began from $400 \mathrm{CE}$ - from the time of Pelagius extending up to the 17th century when the CalvinistArminian debate began, and was passed on to contemporary Christianity (cf. Sell 1998:1-26).

Pelagius and Augustine pioneered two notable streams of thought on the concept of original $\sin .{ }^{8}$ Pelagius (cited by Rees 1991:36-37) contended that original sin did not render sinners incapable of choosing God without any special divine aid. In fact, God gave the gift of free will, because God knew that we can will to choose his ways, for if it were not so, God could not have given us free will, because he knows that we will always choose that which is evil, rendering the gift of free will meaningless. Pelagius (quoted by Rees 1991) remarked:

It was because God wished to bestow on the rational creatures the gift of doing good of their own free will and the capacity to exercise free choice, by implanting in human beings the possibility of choosing either alternative ... They could not claim to possess the good of their own volition, unless they were the kind of creatures that could also possessed evil. Our most excellent Creator wished us to be able to do either but actually to do only one, that is, good, which He also commanded, giving us the capacity to do evil only so that we might do His will by exercising our own. That being so, this very capacity to do evil is also good - good, I say, because it makes the good part better by making it voluntary and independent, not bound by necessity but free to decide for itself. (p. 37)

Contrary to this, Augustine, Gerald and Honan (2010:262) argues for the absolute transmission of Adam's sin to his descendants - that being hereditary, a defiled nature is borne in the soul and body of all human beings by reason of the original sin. Augustine added, 'All human beings, consequently, without a single exception, were dead through sin, original sin.' Hence, there is nothing in the 8.There are other theories beyond Pelagianism, but they are non-Christian which automatically disqualifies them as a basis for this article. 
sinner to assist himself or herself in the endeavour to work towards salvation.

These two clashing theologies have become important, if not overriding, in soteriological discourse. Analogous in both perspectives is the evident importance of God's grace in human salvation which was evident throughout human existence, even when Adam ate the fruit from the tree of good and evil that was forbidden by God (Gn 2:16-17). How did God show his grace to humans even in the garden? Cortez (2012) wrote:

What did the almighty God of the universe do when His creatures sinned against Him? He searched for them, He found them, and He spoke to them (Gn 3:9). God spoke; 'And the Lord God made for Adam and for his wife garments of skins and clothed them' (Gn 3:21). He does not leave them in their shame and nakedness, but He provides a covering. God provided; 'I will put enmity between you and the woman, and between your offspring and her offspring; he shall bruise your head, and you shall bruise his heel' (Gn 3:15). God promised that He will send someone who will strike back against the sin and evil that threatened His creation, His people, and His plan. (n.p.)

And true enough, Jesus died on the cross, destroying the throngs of sin so that sinners could be saved once and for all. When Adam and Eve ate the fruit of the tree of good and evil, God still showed them mercy and instead of fulfilling the wages of their sin - death - without any recourse, he himself gave a remedy so that humanity may be redeemed. This is his grace (Xáprs - something worthy of thankfulness) to us.

To strike a compromise between Pelagius' and Augustine's theses, Semi-Pelagianism became popular. It holds that firstly, grace is the external prerequisite for salvation (Augustinian view). Grace as an external prerequisite means nobody can be saved without it, without a grant from God; secondly, grace is, however, not necessary to make a start towards salvation (Pelagian view); thirdly, predestination is understood in light of prescience (Augustinian view) or God's foreknowledge of human future actions or decisions; and fourthly, those who cooperate with grace are saved, others who choose not to, will be lost (see Gore 2016). For Semi-Pelagianism, sinners are spiritually sick, but not entirely dead. Weber (1988: essay 1) writes that salvation means being liberated from (this) sickness. Likewise, Bellah (1999:277-304) advocates that spiritual health meant salvation - spiritual health that we can either accept or reject.

Wesley's view on this matter is more compromising. Wesley (1856:37) taught that humans are radically corrupted because of sin, but not entirely defiled. Following Paul's teaching, Wesley himself acknowledged that humans were spiritually dead, but his concept of Christian anthropology consists of Semi-Pelagianism, leaning towards the Augustinian perspective.

The Augustinian perspective that human beings are totally corrupted so that they cannot contribute to anything good nor can they entirely cooperate with God, means that nothing
(0\%) good can be attributed to human beings (Augustine 1953:219, 381). This drives a functional frustration and desperation for the sinner. For if none can be attributed to anyone who is spiritually dead, then there spawns a desperate need for the mercy and grace of God, who we know, is the only one we can plead to, because there is nothing in us, not even a single attribute, to save us from damnation. Our sense of nothingness allows God to bring about our salvation. Therefore, we recognise that there cannot be any merit in ourselves, but everything (100\%) only in God.

The Pelagian perspective that human-will, as a creation of God, is independently sufficient to lead a sinless life (Rees 1991:36-38, 43), eventually results to a realisation that sinners have a certain capacity to achieve salvation and that salvation requires human effort. Following this thought, it can be syllogistically concluded that this perspective implies that salvific discretion is fully ours to own and that salvation relies heavily on human prerogative. This overemphasis on human effort adversely means a lesser marvel on God's hand in salvation. There is an overconfidence placed in the human ability and therefore less reliance on God's power to unfold. Eventually, God becomes an external party to the salvation process whose role in salvation will wholly depend on the decision of the sinner whether to allow him to intervene or not at all. This draws out a conclusion then that God is at the mercy of human free will, acting only when we choose to allow him in our lives. Thus, in this case, God's glory is not at all served and is rather put into mockery.

Semi-Pelagianism sought to strike a balance between these two theologies - by forging a cooperation between human faith and God's grace (hence, the 50-50 collaboration) (cf. Weaver 1996:15). The term cooperation itself, implies a 'joint-effort' where one is indispensably needed for the other to fulfil a purpose. Hence, without any human initiative to accept salvation, God cannot apply his grace nor work out his plans for salvation. In the same way, without God's grace, we are not able to achieve salvation and walk a Christian life. This, however, compromises the glory that should be purely God's, as it presupposes a proportionate distribution of merit to where it seems due - in this case, glory is given to God, but credit is also attributed equally to human effort. Ultimately, God cannot be said to have deserved all the recognition if the sinner inevitably has to have a share in it.

In his journal, Wesley (1828) wrote:

I think on justification just as I have done any time these sevenand-twenty years, and just as Calvin does. In this respect I do not differ from him a hair's breadth. (p. 560)

Wesley and the Arminians' perspective is indeed a hair's breadth away from Calvin's view. Calvin argues that human beings are totally depraved because of sin, and therefore, they are spiritually dead. Wesley and his fellow Arminians acknowledged the idea that human beings are indeed in bondage to sin so that we cannot freely act with faith apart from God's enabling power (Olson 2009:137-157); such is 
also held by Calvin. However, the Arminian theology of prevenient grace runs contrary to the implications of total depravity (Schreiner 2000:232-233). Wesley (cited by Field 2015:1-13) insisted that there is a measure of free will restored in every human being. By the Wesleyan-Arminian view, it may be inferred that, although humans are depraved, we are not totally divested of our human-wills. According to this view, while God's grace is imperative, it is not the only requirement. The formula accommodates a slither of necessity to will for our salvation, because it is reasonable to defend the principle of moral responsibility, even in salvation. Ultimately, again in this case, the glory ascribed to God cannot be said to be full and exclusively his alone.

The Reformers were hugely influenced by Augustine's works. Warfield (1905:126) wrote, 'It is Augustine who gave us the Reformation.' Augustine had a huge impact on the Reformation fathers. Luther himself was an Augustinian monk. Calvin, in his writings, often quoted Augustine. According to Sproul (1996:2), the Reformation's roots were 'planted by Augustine'. The reformed tradition is unique, among others, because of its concept on God's sovereignty which takes primacy over all else. This could be further broken down into two concepts: Firstly, grace is available to all people (common grace); secondly, a special kind of grace is, however, reserved and given to a particular people (particular grace) (Bavinck 1989:35-65; Inst. 3.21.1). These two reformed features of grace is what is intended by Calvin's statement that there is 'sufficient grace to all but efficient only to the elect' (Inst. 2.17.1; 3.2). The two kinds of grace contemplated here, is the katallasso and the hilaskomai. Katallasso is the common grace and the hilaskomai is particular grace. While everyone experiences the grace of God in everyday life, such as the provision of life itself and the necessities of living, a special order of grace, which enables and directs a particular people to come to the knowledge of God, is set apart for those whom God decides to give it to. Nicole (1985) said:

What Christ has accomplished on the cross is not so much to secure the salvability of all humans, as actually to accomplish the salvation of those whom He does redeem. (p. 13)

God, in his incontestable sovereignty, chose to set apart a people unto himself that the suffering of Christ may not go to waste, because redemption was costly (Van Genderen \& Velema 2008:482). Thus, if God chose to leave the decision of salvation solely to the decision of the sinner, there could never be salvation, because a sinner will never choose what is godly because the sinner is completely yielded to the consequences of $\sin$ - death. For indeed, how can one who is dead, be able to decide and do?

It is easy to question such position, because if God loves the world, how can he now choose a few and allow the rest to suffer eternal damnation? This is where the Reformists insist on the sovereignty and wisdom of God, which if inquired into, will only frustrate the futility of human mind. God is a God of order. He neither commits accidents or mistakes, nor does he go wrong. He is God. His plan is perfect in a way that human reason cannot contrive. This, however, implies that it is absolutely God's doing that there can ever be salvation to those whom God has set apart for reasons no human mind can ever understand. In such case, there is nothing in the sinner that may be credited. Bonhoeffer (1959:43-45) enjoined, 'Don't cheapen [the grace of God] by inserting human ability whether to choose or reject the grace He bestowed.' Thus, atonement is limited only to the elect, but sufficient to all so that it may be called a privilege and a gift ( $\chi \alpha$ ópı or grace) something that cannot be taken for granted and should not be cheapened.

\section{Grace revolution}

The Grace Revolution Movement has been making powerful inroads into the Christian churches despite of some aggregate oppositions. According to Brown (2014:8-11), the Grace Revolution seeks to transform or reform the church, because the gospel of grace is not completely and truthfully taught in the church. Thus, it seeks to reclaim the primacy of grace and take a central position in Christian thought so that the doctrine of the church will flow from a grace perspective. Whitten (2012:25-26) claims that there is a need for revolution, because little has changed in the Protestant church in more than 500 years - in which he said that the church message had and has been missing the true gospel message of grace. He conceded that Luther and Calvin got it right concerning justification or how one is saved, but he argued that, somehow Luther and Calvin missed the true message of sanctification or how one is perfected into the likeness of Christ; thus, the movement insisted on a theological revolution.

Brown (2014:6), however, classified this movement under the umbrella of hyper-grace teaching, because according to him, the so-called Grace Revolution teachings have exaggerated the implications and extents of God's grace. Crowder (2015), a revolutionist, reposed that such is the nature of grace - that indeed, it must be viewed 'hyperly', because to do otherwise, will limit its depths and essence of the revelation of Christ and primarily because the 'scandal of grace' is indeed so scandalous. Brown (2016:17) and Ravenhill (2013: par. 12) reasoned that the danger of viewing grace 'hyperly' is the sensible tendency to misinterpret it as a license to sin. In such case, it ultimately runs contrary to what Paul warned in the Bible, ${ }^{9}$ which is that grace should not be used to cheapen its true meaning (cf. Bonhoeffer 1959:43-45). Brown and Ravenhill cautioned that such is a fatal standpoint because it goes beyond biblical interpretation, misleading many believers into confusion and weakness in their confession of sin and repentance.

In essence, the Grace Revolution message contends that God does not see our sins anymore, because Jesus died for all our sins of the past, present and future; hence all of our sins in the past, present and future had already been forgiven

9.What shall we say, then? Shall we go on sinning so that grace may increase? By no means! We are those who have died to sin; how can we live in it any longer? (Rm 6:1-2, NIV) 
by God. Therefore, confession of sin and repentance is no longer necessary, as spirituality should be absent of human effort (Crowder 2010:9, 39; Dunn 2011:141; Prince 2010:xii, 145, 341; Wommack 2011:39-40). It teaches perfection in Christ through confession of faith. Prince $(2010: 145,341)$ says that the moment we accepted Jesus as our saviour, God gave us an 'eternal "A+" for our right standing with Him'. Whitten (2012:66) writes, 'you are like Him, my friend, and are in a permanent and unchangeable state of being of holiness'. Crowder (2010:42) said, 'the moment you decide to do something to be holy, you have trusted in yourself, instead of Christ, for salvation'. These imply that sanctification is not a spiritual progressive process. Likewise, Ellis (2012) preached that:

there is nothing wrong with wanting to better yourself, but you have to understand that in Christ, you are already as good and pleasing to God as you ever will be. But don't confuse behaviour with identity. You are not defined by what you do. Your identity is Christ and in Him, you are and always will be $100 \%$ pleasing and acceptable to God. (p. 112)

Ellis' message seeks to convince Christians that they are perfect, $100 \%$ pleasing and acceptable to God - no matter what they do. Rufus (2011), in support of Crowder's position, said that:

sanctification isn't a process! We do not become more and more holy. No! We become holy once and for all! We become sanctified once and for all. Now the life we live is the overflow of what has happened, that miracle overflowing through our mind and through our body! (n.p.)

Prince (2007) also teaches that sanctification is not a process but a person, Jesus Himself. He writes:

stop examining yourself and searching your heart for sin. Remember that when someone takes his sin offering to the priest, the priest does not examine him. He examines the sin offering. (p. 187)

He referred to the offering as the works of Jesus and insisted on a Jesus-focused preaching rather than a sin-conscious one.

If we are to examine this so-called new concept of grace through the anthropological test, it will eventually appear that this is not a revolutionary new teaching. In fact, Pelagius had the same thesis - by the mere confession that Christ is our righteousness, we become like him: holy and righteous. Oppositions claim that this is not the concept of grace contemplated by Paul in the Bible (Hoehner 2002:497-817). Such teaching is merely an outcrop of the Pelagian anthropology which holds that sinners retain spiritual wellness and are therefore capable of independently walking a godly life and achieving salvation.

To say that our sins of the past, present and future have been forgiven, and that we are totally blameless would entail the emphasis on katallasso [common grace] erroneously making it the exclusive and full meaning of God's grace in salvation and in the Christian walk, homogenising it with hilaskomai [special grace] as if it were also katallasso - grace which is available to everyone. Katallasso is for everyone, regardless if it is accepted or otherwise. It is freely given, because God has willed it so, but hilaskomai is a special and a different kind of grace - only given to those whom God has chosen to reveal it to. According to Manning (2008:21), the gospel of grace is Christ suffering and dying for all sinners. He argued that salvation is for all. He taught that the gospel of grace accepts us all no matter what we are like. We just need to come before the cross and confess that Jesus is our righteousness, regardless of our struggles with sin and waywardness. God is pleased with us through Christ - no matter who we are or were, and what we did, do and will do. However, hilaskomai is not generally applied to all, but it is of special application, for God, even as a Father, does not spoil his children, but disciplines them so that his children may walk according to his ways. Instead of allowing his children to keep sinning, he enables them by his grace to walk a holy life by his spirit. Such grace is costly, because it calls us to follow Christ (Bonhoeffer 1959:43-45) and turn from our own ways. However, such grace is not for ourselves to choose, but for God. He chooses to whom he will appropriate such special grace so that the chosen may come to the knowledge and salvation of Christ, because, without this kind of grace, we cannot at all choose to walk in his ways. Besides, how can the dead independently will or do? Thus, an anti-Pauline (unbiblical) grace asserts that sinners are not totally dead in their state of being so that they can choose to walk in the ways of God and thus work their merit towards salvation.

\section{Conclusion}

Pauline grace presents the biblical origins of Christian anthropology, soteriology and perfection. It was first conveyed to the Church Fathers and then to the Reformist Fathers. Any teaching departing from the message of Paul shall be treated as mere speculation. Calvin says that it is imperative to be sure of the message of the Scripture not so that we can theorise or discuss theological conjectures, but so that we can be founded concretely on the basis for trusting God, to 'banish all doubt' (Inst. 1.6.3). The Reformists read the Bible from a redemptive-historical perspective in which God's grace is acknowledged as a 'self-revelation of God' (Vos 2003:5-9). Calvin's writings hinged on the notion that the Bible was a means for human beings to come to the knowledge of God (Inst. 2.1.6). Calvin stresses that the point is not that we should know Scripture, but that we should, through Scripture, know God.

It is important to examine grace teachings with utmost diligence, as we should to other teachings so that there can be a faithful exaction of teachings with the message of Scripture; hence, the need to trace the message through its anthropological thesis. In such case, exegesis to determine its origins and intentions, is proper. This is the challenge that Paul calls Christians to live up to - the same challenge he gave to Timothy: 'Do your best to present yourself to God as one approved, a workman who does not need to be ashamed 
and who correctly handles the word of truth' (2 Tm 2:15-NIV) so that, before God, we can all say what Paul said:'I have fought the good fight, I have finished the race, I have kept the faith' (2 Tm 4:7 - NIV).

There is no better time to be adept and faithful with the message of Scripture than in contemporary Christianity which is inundated with various teachings that claim to bear the seal of the gospel truth, but in fact depart from the message of Scripture, leading many believers to a misplaced belief. Packer (1926:1) said, 'to recover the old, authentic, biblical gospel, and to bring our preaching and practice back into line with it, is perhaps our most pressing present need'. Like Calvin and the Reformers, the church today needs to stand on the shoulders of the church fathers, just as the church fathers stood atop the apostles and the prophets (Brunner 2014:90-91). By this we mean that the church ought to learn from the experience of the Church Fathers and avoid the errors of the past. There is no space for subjective inference and personal colourings in biblical hermeneutic. Permission is given not to be guided by human personal considerations, but to be guided by the pronouncement of the Scripture. Van Genderen and Velema (2008:478-479) warn that those who pursue scenarios that are not supported by the Scripture 'engage in pure speculation and does not therefore bear authority'.

Therefore, a new, progressive or revolutionary teaching on grace must be tested through the scriptural crucible. We need to be certain - not just confident - that the tradition we follow is in keeping with the true message of grace. In terms of the role of grace in human salvation, the test for theologies will always be whether the grace taught, will ultimately and exclusively attribute glory to God - all Glory, to God alone.

\section{Acknowledgements}

To my fiancée, Stephanie L. Baucas, for all the support you have showed me in my academic journey in South Africa and for your relentless love to me. I got so much motivation to accomplish this article because of you.

\section{Competing interests}

The author declares that he has no financial or personal relationships which may have inappropriately influenced him in writing this article.

\section{References}

Arminius, J., 1853, Complete works of Arminius (On the free will of man and its powers), vol. 1, Derby \& Miller, Auburn, New York, NY. (Public disputations of Arminius, Disputation 11).

Arnold, C., 2008, Exegetical commentary on the New Testament, Zondervan, Grand Rapids, MI.

Arnold, C., 2011, Ephesians, Zondervan, Grand Rapids, MI.

Augustine, A., 1953, Augustine: Earlier writings, vol. 6, Westminster John Knox Press, Louisville, KY.

Augustine, S., Gerald, G.W.S. \& Honan, D.J., 2010, The city of God, books xvii-xxii, The Catholic University of America Press, Washington, D.C. (The fathers of the church, 24).

Barclay, J.M.G., 2015, Paul and the gift, Wm. B. Eerdmans Publishing Co., Grand Rapids, MI.
Barclay, M., 1988, Obeying the truth: Paul's ethics in Galatians, T\&T Clark, Edinburgh. Bavinck, H., 1989, 'Common grace', Calvin Theological Journal 24(1), 35-65.

Becker, J., 1993, Paul: Apostle to the gentiles, Westminster John Knox Press, Louisville, KY. Bellah, R.N., 1999, 'Max Weber and world-denying love: A look at the historical sociology of religion', Journal of the American Academy of Religion, 67(2), 277-304. https:// doi.org/10.1093/jaarel/67.2.277

Berkhof, L., 1996, Systematic theology, Wm. B. Eerdmans Publishing Co., Grand Rapids, MI.

Bible Hub, 2016, Propitiation: Ephesians 1:7, viewed 06 October 2016, from http:// biblehub.com/ephesians/1-7.htm

Bonhoeffer, D., 1959, The cost of discipleship, Touchstone, New York, NY.

Brown, M.L., 2014, Hyper-grace: Exposing the dangers of the modern grace message, Charisma Media, Lake Mary, FL.

Brown, M.L., 2016, The grace controversy: Answers to 12 common questions, Charisma House, Lake Mary, FL.

Bruce, F.F., 1984, The epistles to the Colossians, to Philemon, and to the Ephesians, vol. 10, Wm. B. Eerdmans Publishing Co., Grand Rapids, MI.

Brunner, E., 2014, The Christian doctrine of the church, faith, and the consummation: Dogmatics, vol. 3, Wipf \& Stock Publishers, Eugene, OR.

Bufford, R.K., 2015, 'Encountering grace march', PhD dissertation, George Fox University, Newberg, OR

Calvin, J., 1536, Institutes of the Christian religion, transl. L. Battles, Wm. B. Eerdmans Publishing Co., Grand Rapids, MI.

Calvin, J., 1961, Concerning the eternal predestination of God, James Clarke \& Co., Cambridge, UK.

Campbell, D.A., 2009, Deliverance of God: An apocalyptic reading of justification in Paul, Wm. B. Eerdmans Publishing Co., Grand Rapids, MI.

Carson, D.A., 1992, Justification in the Bible and the world, Paternoster Press, Carlisle, UK.

Carson, D.A. \& Moo, D.J., 2009, An introduction to the New Testament, HarperCollins Christian Publishing, Nashville, TN.

Chester, S.J., 2017, Reading Paul with the Reformers: Reconciling old and new perspectives, Wm. B. Eerdmans Publishing Co., Grand Rapids, MI.

Coleridge, S.T., 1858, Specimens of the table talk, John Murray, London.

Cortez, M., 2012, What did God do after Adam and Eve sinned?, viewed 24 April 2017 from https://www.westernseminary.edu/transformedblog/2012/04/16/whatdid-god-do-after-adam-and-eve-sinned-a-childs-answer-reveals-a-big-problem/

Crowder, J., 2010, Mystical union, Sons of Thunder, Santa Cruz, CA.

Crowder, J., 2015, Jesus the refugee - the Jesus trip, viewed 21 April 2017, from https://www.youtube.com/watch?v=gX5h74LK3ZA

Dodd, C.H., 1929, 'Ephesians', in F.C. Eiselen, E. Lewis \& D.G. Downey (eds.), The Abingdon Bible commentary, pp. 1224-1225, Abingdon Press, Nashville, TN.

Drury, D., 2006, Three: Sixteen this changes everything: A message manuscript, viewed 06 September 2017, from http://www.drurywriting.com/david/06.three. sixteen.htm

Dunn, B., 2011, The happy gospel: Effortless union with a happy God, Destiny Image, Shippensburg, PA.

Dunn, J.D.G., 1998, Theology of Paul the Apostle, Wm. B. Eerdmans Publishing Co., Grand Rapids, MI.

Ellis, P., 2012, The gospel in ten words, KingsPress, Birkenhead, NZ.

Field, D.N., 2015, 'John Wesley as a public theologian: The case of thoughts upon slavery', Scriptura 114(1), 1-13. https://doi.org/10.7833/114-0-1136

Furnish, V., 1968, Theology and ethics in Paul, Abingdon Press, Nashville, TN.

Gaffin, Jr. R., 2006, By faith, not by sight: Paul and the order of salvation, Paternoster, Waynesboro, GA.

Gaffin, Jr. R., 2012, 'The redemptive-historical view', in S.E. Porter \& B.M. Stovel (eds.), Biblical Hermeneutics: Five views, pp. 89-110, InterVarsity Press, Downers Grove, IL.

Gore, B.W., 2016, 'Pelagian controversy', viewed 18 February 2017, from https://www. youtube.com/watch?v=s6_GcYp-9xA

Hoehner, H.W., 2002, Ephesians: An exegetical commentary, Baker Book House, Grand Rapids, MI.

Heil, J., 2007, Ephesians: Empowerment to walk in love for the unity of all in Christ vol. 13, Society of Biblical Literature, Atlanta, GA.

Inst. see Calvin 1536

Jakes, T., 2008, Life overflowing, 6-in-1: 6 pillars for abundant living, Baker Book House, Grand Rapids, MI.

Kainer, G., 2015, God's grace: A gift freely given, 1st edn., Lulu.com, Morrisville, NC.

Kostenberger, A.L., Kellum, L.S. \& Quarles, C.L., 2012, The lion and the lamb: New Testament essentials from the cradle, the cross, and the crown, B \& H, Nashville, TN.

Lindsay, J., 1939, 'Predestination', in J. Orr, J. Nuelsen, E. Mullins, et al. (eds.), International Standard Bible Encyclopaedia Online, vol. 4, pp. 2435-2437, Wm. B. Eerdmans Publishing Co.,Grand Rapids, MI.

Manning, B., 2008, The ragamuffin gospel: Good news for the bedraggled, beat-up, and burnt out, Multnomah, Colorado Springs, $\mathrm{CO}$.

McCarthy, J.G., 2010, Eklego, eklogee, eklektos, suneklektos: John Calvin goes to Berkeley, City Christian Press, Portland, OR. (Word study, 1). 
McCartney, G., 2003, Should we employ the hermeneutics of the New Testament writers?, viewed 07 August 2017, from http://www.bible-researcher.com/ mriters?, viewed

Meyers, R., 2016a, Predestinated - a commentary to Ephesians 1:5, viewed 26 March 2016, from www.e-sword.net

Meyers, R., 2016b, Thayer's definition of $\pi \rho \circ \rho \rho i \zeta \omega$, viewed 26 March 2016, from www.e-sword.net

Meyers, R., 2016c, Vincent's word studies, viewed 28 March 2016, from www. e-sword.net

Meyers, R., 2016d, Thayer's description of ä $\varphi \varepsilon \sigma \iota \varsigma$, viewed 28 March 2016, from www.e-sword.net

Moo, D., 1996, The epistle of the Romans, Wm. B. Eerdmans Publishing Co., Grand Rapids, MI.

Mueller, T., 1982, 'Justification: Basic linguistic aspects and the art of communicating it', Concordia Theological Quarterly 46(1), 21-38.

Nestle, E.B., 1967, Novum Testamentum Graece, United Bible Societies, London, UK.

Nicole, R.R., 1985, 'John Calvin's view of the extent of the atonement', Westminster Theological Journal, 47(2), 197-199.

O'Brien, P., 1979, 'Ephesians: An unusual introduction to a New Testament letter', NTS 25, 504-516. https://doi.org/10.1017/\$002868850000521X

Olson, R.E., 2009, Arminian theology: Myths and realities, InterVarsity Press, Downers Grove, IL.

Packer, J.I., 1926, The Death of Death in the Death of Christ, Lulu.com, Morrisville, NC.

Prince, J., 2007, Destined to reign: The secret to effortless success, wholeness and victorious living, Harrison House Publishers, Tulsa, OK.

Prince, J., 2010, Unmerited favour, Charisma House, Lake Mary, FL.

Ravenhill, D., 2013, 'Would you recognize the deception of hyper-grace?', CHARISMANEWS, viewed 19 April 2017, from http://www.charismanews.com/ opinion/39494-would-you-recognize-the-deception-of-hyper-grace

Rees, B.R., 1991, The letters of Pelagius and his followers, Boydell Press, Suffolk, UK.

Robichaux, K., 2000, Perspectives on grace, viewed 08 August 2017, from http://www. affcrit.com/pdfs/2000/04/00_04_a1.pdf

Robinson, J.A.T., 1907, St. Paul's epistle to the Ephesians, 2nd edn., Macmillan \& Co., London, UK.

Robinson, J.A.T., 1979, Wrestling with Romans, Westminster Press, Philadelphia, PA.

Rondinone, J., 2012, Overcoming: Living victoriously in Christ, Xulon Press, Maitland, FL.

Rufus, R., 2011, 'Totally forgiven! Totally united! Totally filled! Sermon preached at the grace and glory conference', viewed 10 June 2017, from http://ryanrufus. blogspot.com/2011/06/ryan-rufus-on-mortifying-sin.html

Russell, W., 1995, 'The Apostle Paul's redemptive-historical argumentation in Galatians 5:13-26', Westminster Theological Journal 57, 333-357.

Ryrie, C.C., 1963, The grace of God, Moody Press, Chicago, IL.

Sanders, E.P., 1977, Paul and Palestinian Judaism, Fortress Press, Philadelphia, PA.
Schreiner, T., 2000, 'Does scripture teach prevenient grace in the Wesleyan sense?' in T.R. Schreiver \& B.A. Ware (eds.), Still sovereign: Contemporary perspectives on election, foreknowledge, and grace, pp. 229-246, Baker Academic, Grand Rapids, MI.

Schreiner, T., 2011, Interpreting the Pauline epistles, Baker Academic, Grand Rapids, MI. Scofield, C., 2004, The Scofield Study Bible, vol. 3, Oxford University Press, Oxford, UK. Sell, A.P, 1998, The great debate: Calvinism, Arminianism and salvation, Wipf \& Stock, Eugene, OR.

Sproul, R.C., 1996, Augustine and Pelagius, Ligonier Ministries, Orlando, FL.

Strong, J., 1997, Greek dictionary of the New Testament (PDF), The AGES Digital Library, Albany, OR.

Stuhlmacher, P., 2001, Revisiting Paul's doctrine of justification: A challenge to the new perspective, InterVarsity Press, Downers Grove, IL.

Thayer, J., 1996, Greek-English lexicon of the New Testament, Hendrickson, Peabody, MA

The International Standard Bible Encyclopaedia, 1986, Paul, the apostle, vol. 3, Wm. B. Eerdmans Publishing Co., Grand Rapids, MI.

Van Genderen, J. \& Velema, W.H., 2008, Concise reformed dogmatics, P\&R Publishing, Phillipsburg, NJ.

Vos, G., 2003, Biblical theology: Old and New Testaments, Wipf \& Stock Publishers, Eugene, OR.

Warfield, B.B., 1905, Augustine and his confessions, s.n., The Princeton Theological Review 3(1), 81-126.

Warfield, B.B., 2000, The plan of salvation, Wipf \& Stock Publishers, Eugene, OR.

Weaver, R.H., 1996, Divine grace and human agency: A study of the Semi-Pelagian controversy, The Catholic University of America Press, Washington D.C.

Weber, M., 1988, 'Die Wirtschaftsethik der Weltreligionen: Vergleichende religionssoziologische Versuche,' in Gesammelte Aufsätze zur Religionssoziologie, 9th edn., UTB/Mohr, Tubingen, Germany.

Wesley, J., 1755, Predestination calmly considered, ed. H. Cock, Tine Bridge, Newcastle. Wesley, J., 1828, The journal of the rev. John Wesley, London, UK.

Wesley, J., 1856, Sermons, vol. 2, Carlton \& Lanahan, New York, NY.

Westerholm, E., 1992, Romans, Wm. B. Eerdmans Publishing Co., Grand Rapids, MI.

Whitford, D. (ed.), 2012, The T\&T Clark companion to reformation theology, T \& T Clark International, New York, NY.

Whitten, C., 2012, Pure grace: The life changing power of uncontaminated grace, Destiny Image Publishers, Shippensburg, PA.

Wigram, G. \& Winter, R., 1978, The word study concordance, William Carey Library, Pasadena, CA.

Wommack, A., 2011, Effortless change: The word is the seed that can change your life, Kindle edn., Harrison House, Tulsa, OK.

Wright, N.T., 2013, Paul and the faithfulness of God, Fortress Press, Minneapolis, MN. Yarchin, W., 2004, History of biblical interpretation: A reader, Hendrickson Publishers, Peabody, MS. 